\title{
ВПЛИВ ГЛУТАТІОНУ НА БІОХІМІЧНІ ПОКАЗНИКИ СИРОВАТКИ КРОВІ ПРИ ЕКСПЕРИМЕНТАЛЬНІЙ НЕФРОПАТІЇ
}

Вступ. Захворювання нирок - одна з найпоширеніших та найактуальніших проблем сучасної медицини. В останні десятиліття активно вивчають нефропротекторні властивості різноманітних антиоксидантів з метою попередження та корекції порушень функцій нирок, однак дані щодо ролі різних антиоксидантів є фррагментарними і потребують подальших досліджень.

Мета дослідження - вивчити вплив глутатіону на зміну біохімічних показників крові за умов експериментальної нефропатії.

Методи дослідження. Досліди проводили на 90 білих статевозрілих щурах-самцях масою 0,16-0,18 ке. У двох серіях експериментів нефропатію викликали шляхом одноразового внутрішньочеревного введення фолієвої кислоти в дозах 200 та 250 мг/ка. Глутатіон вводили інтрагастрально в дозі 100 мг/кг упродовж трьох та семи днів. Для оцінки фрункціонального стану нирок проводили біохімічне дослідження крові 3 визначенням концентрації креатиніну, сечовини, альбуміну, загального білка, активності у-глутамілтранспептидази та аланіламінотранспептидази.

Результати й обговорення. За умов нефропатії спостерігали збільшення вмісту сечовини порівняно з контрольною групою: на $27 \%$ - на третій день експерименту, на 15 \% - на сьомий. Введення глутатіону сприяло нормалізації досліджуваного показника. Було відзначено підвищення, порівняно з контрольною групою, рівня креатиніну в сироватці крові щурів із нефропатією в 1,5 раза при застосуванні фролієвої кислоти в дозі 200 мг/ке. На сьомий день експерименту він збільшився лише на 17 \%. У групі тварин, в яких нефропатію викликали фролієвою кислотою в дозі 250 мг/кг, концентрація креатиніну підвищилась порівняно з контрольною групою: у 2,4 раза - на третій день експерименту, на 30 \% - на сьомий. Семиденне введення глутатіону прирівнювало показники креатиніну піддослідних тварин до показників контрольної групи. Про загальну інтоксикацію організму під впливом високої концентрації фолієвої кислоти свідчили зниження білоксинтезувальної функції печінки, зростання активності у-глутамілтранспептидази та аланіламінотранспептидази.

Висновки. Глутатіон проявляє несропротекторні властивості, що підтверджується зниженням проявів нефротичного синдрому та поліпшенням фрункціональних показників нирок. Найбільш чутливий біохімічний показник за умов нефропатії - креатинін, вміст якого залежить від концентрації токсиканта, можна використовувати для діагностування стану нирок та підтвердження моделі нефропатії.

КЛЮЧОВІ СЛОВА: нефропатія; креатинін; глутатіон; фолієва кислота.

ВСТУП. Захворювання нирок - одна з найпоширеніших та найактуальніших проблем сучасної медицини. Метаболічні порушення, які спостерігають у процесі розвитку нефропатій, часто призводять до гіпоксії та змін у системі енергетичного забезпечення клітин організму, зумовлюють генерацію вільних радикалів, що ушкоджують ліпідні та білкові компоненти клітин, сприяють утворенню і накопиченню ліпопероксидних сполук, у результаті чого посилюють процеси дестабілізації клітинних мембран, провокуючи ускладнення хвороб. Швидкість прогресування ниркової патології обґрунтовує пошук антиоксидантів із нефропротекторною дією.

(ㄱ.В. Геруш, Н. П. Григор'єва, Є. О. Ференчук, 2018.
В останні десятиліття активно вивчають нефропротекторні властивості різноманітних антиоксидантів з метою попередження та корекції порушень функцій нирок, однак окремі дані щодо ролі різних природних і синтезованих антиоксидантів $€$ фррагментарними та потребують подальших досліджень.

Відомо, що найбільш інтенсивно епітеліальні клітини, в тому числі епітелій проксимальних ниркових канальців, захоплюють та використовують циркулюючий глутатіон $[1,2]$, що дає підґрунтя для дослідження його ролі при розвитку нефропатії. Глутатіон відіграє вагому роль у клітинному обміні, бере участь у підтримці окиснювально-відновного потенціалу, процесах 
детоксикації ксенобіотиків ендо- та екзогенного походження як безпосередньо, так і в якості субстрату для фрерментів біотрансорормації. Розвиток багатьох гострих та хронічних захворювань супроводжується варіабельністю рівня глутатіону та окиснювального стресу в клітинах $[3,4]$.

Мета дослідження - вивчити вплив глутатіону на зміну біохімічних показників крові за умов експериментальної нефрропатії.

МЕТОДИ ДОСЛІДЖЕННЯ. Досліди проводили на 90 білих статевозрілих щурах-самцях масою 0,16-0,18 кг. У двох серіях експериментів нефропатію викликали шляхом одноразового внутрішньочеревного введення фолієвої кислоти в дозах 200 та 250 мг/кг. Піддослідних тварин було поділено на 3 групи: 1-ша - контрольна; 2-га - тварини з експериментальною нефрропатією; 3-тя - тварини з нефропатією, яким вводили глутатіон. Глутатіон вводили інтрагастрально в дозі 100 мг/кг. Щурів виводили з експерименту наступного дня після останнього введення глутатіону. Досліди виконували відповідно до положень Загальних етичних принципів експериментів на тваринах, ухвалених на Першому національному конгресі з біоетики (Київ, 2001), Європейської конвенції про захист хребетних тварин, що використовуються для дослідних та інших наукових цілей (Страсбург, 1986). Концентрацію загального білка визначали біуретовим методом, альбуміну - за реакцією з бромкрезоловим зеленим, сечовини - ферментативним уреазним методом, використовуючи реактиви виробництва ПрАТ "Реагент" (Україна); концентрацію креатиніну - модифрікованим методом Яфрфе [5]; активність аланінамінотрансферази (АлАТ) - кінетичним методом без піридоксаль- 5-сроссрату, що базується на різниці поглинання окисненої та відновленої форм нікотинамідаденіндинуклеотиду; активність у-глутамілтранспептидази (ГГТ) за реакцією швидкості утворення 5-аміно-3нітробензоату із застосуванням реагентів фрірми "Cormay" (Польща). Оптичну густину продуктів реакцій вимірювали на спектрофотометрі "Agilent Cary 60". Статистичну обробку отриманих даних проводили за допомогою непараметричного критерію Вілкоксона. Результати вважали достовірними при $р<0,05$.

РЕЗУЛЬТАТИ Й ОБГОВОРЕННЯ. Несрротоксична дія багатьох токсичних хімічних сполук та лікарських засобів часто має локальний характер: більшість несрропатій супроводжується прогресивним запаленням гломерул, що, зрештою, призводить до їх лізису [6].
Особливу увагу при діагностуванні захворювань нирок приділяють рівню виділення продуктів азотистого обміну: креатиніну і сечовини, а також продуктів білкового обміну.

Найбільш чутливим показником виявився креатинін, вміст якого залежав від концентрації токсиканта (табл. 1). Результати наших досліджень показали, що в процесі розвитку несрропатії в крові накопичувались азотовмісні сполуки, на що вказувало підвищення рівня креатиніну в сироватці крові, порівняно з контрольною групою, в 1,5 раза (табл. 1) при застосуванні фролієвої кислоти в дозі 200 мг/кг. На сьомий день експерименту він збільшився лише на $17 \%$. Триденне введення антиоксиданта сприяло зниженню досліджуваного показника на $25 \%$ порівняно з групою тварин із нефропатією.

У групах щурів, в яких захворювання нирок викликали фолієвою кислотою в дозі 250 мг/кг, на третій день експерименту розвиток несрропатії супроводжувався збільшенням концентрації креатиніну в 2,4 раза порівняно 3 контрольною групою (табл. 1), що підкреслювало погіршення фрільтраційної функції і здатності нирок до виведення з кровотоку продуктів азотистого обміну. На сьомий день експерименту відбулося компенсаторне відновлення фрункції нирок - рівень досліджуваного показника зріс лише на $30 \%$. Зміни вмісту креатиніну залежно від дози фолієвої кислоти дозволяють використовувати його для раннього діагностування стану нирок та підтвердження моделі нефропатії.

На третій день експерименту за умов застосування глутатіону в щурів, у яких нефропатію викликали шляхом введення 250 мг фолієвої кислоти, рівень креатиніну був на $16 \%$ нижчим, ніж у групі тварин, яким глутатіону не вводили, але показники все ж удвічі перевищували показники контрольної групи.

Семиденне введення глутатіону, незважаючи на обрану дозу фолієвої кислоти, прирівнювало показники креатиніну в сироватці крові піддослідних тварин до показників контрольної групи, що вказувало на відновлення фуннкціональної активності нирок та активності виведення продуктів азотистого обміну.

На третій день експерименту за умов фролієвої несрропатії, викликаної дозою 250 мг/кг, у сироватці крові тварин дослідної групи змінювався вміст сечовини, який був вищим на $27 \%$, а на сьомий - на $15 \%$ порівняно з контрольною групою (табл. 2). Відомо, що концентрація сечовини збільшується внаслідок посиленої пасивної реабсорбції в ниркових канальцях.

При порівнянні показників контрольної групи та груп тварин, яким вводили глутатіон, на третій і сьомий дні після моделювання захворювання 


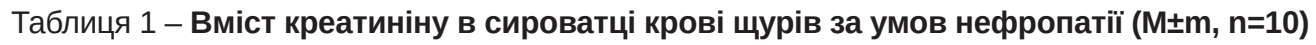

\begin{tabular}{|c|c|c|c|c|}
\hline \multirow[b]{2}{*}{ Контроль } & \multicolumn{4}{|c|}{ Креатинін (мкмоль/л) за умов нефропатії, викликаної фролієвою кислотою в дозі 200 мг/кг } \\
\hline & $\begin{array}{c}\text { несрропатія, } \\
\text { третій день }\end{array}$ & $\begin{array}{c}\text { несрропатія+глутатіон, } \\
\text { третій день }\end{array}$ & $\begin{array}{l}\text { несрропатія, } \\
\text { сьомий день }\end{array}$ & $\begin{array}{c}\text { несрропатія+глутатіон, } \\
\text { сьомий день }\end{array}$ \\
\hline $7,3 \pm 0,56$ & $10,96 \pm 0,18^{a}$ & $8,22 \pm 0,02^{a, b}$ & $8,54 \pm 0,23^{a}$ & $7,25 \pm 0,22^{b, c}$ \\
\hline \multirow[b]{2}{*}{ Контроль } & \multicolumn{4}{|c|}{ Креатинін (мкмоль/л) за умов несропатії, викликаної фролієвою кислотою в дозі 250 мг/кг } \\
\hline & $\begin{array}{c}\text { нефрропатія, } \\
\text { третій день }\end{array}$ & $\begin{array}{c}\text { несрропатія+глутатіон, } \\
\text { третій день }\end{array}$ & $\begin{array}{l}\text { несрропатія, } \\
\text { сьомий день }\end{array}$ & $\begin{array}{c}\text { нефропатія+глутатіон, } \\
\text { сьомий день }\end{array}$ \\
\hline $7,3 \pm 0,56$ & $17,56 \pm 0,18^{a}$ & $15,11 \pm 0,05^{a, b}$ & $9,54 \pm 0,3^{a}$ & $7,35 \pm 0,2^{\mathrm{b}, \mathrm{c}}$ \\
\hline
\end{tabular}

Примітка. Тут і в таблиці 2:

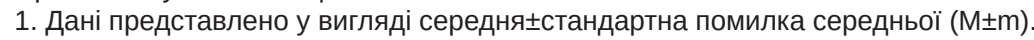

2. a - статистично значущі відмінності порівняно 3 показниками контрольної групи тварин, ${ }^{\mathrm{b}}$ - статистично значущі відмінності порівняно з показниками групи тварин із нефропатією на третій день експерименту; ${ }^{\circ}-$ статистично значущі відмінності порівняно з показниками групи тварин із нефропатією на сьомий день експерименту $(p<0,05)$.

Таблиця 2 - Вміст основних біохімічних показників у сироватці крові щурів за умов нефропатії, викликаної фолієвою кислотою в дозі 250 мг/кг (M $\pm \mathrm{m}, \mathrm{n}=10)$

\begin{tabular}{|l|c|c|c|c|c|}
\hline \multicolumn{1}{|c|}{ Показник } & Контроль & $\begin{array}{c}\text { Нефропатія, } \\
\text { третій день }\end{array}$ & $\begin{array}{c}\text { Несропатія+ } \\
\text { глутатіон, } \\
\text { третій день }\end{array}$ & $\begin{array}{c}\text { Нефропатія, } \\
\text { сьомий день }\end{array}$ & $\begin{array}{c}\text { Нефропатія+ } \\
\text { глутатіон, } \\
\text { сьомий день }\end{array}$ \\
\hline Загальний білок, г/л & $62,6 \pm 0,26$ & $53,54 \pm 0,42^{\mathrm{a}}$ & $56,63 \pm 0,35^{\mathrm{a}, \mathrm{b}}$ & $53,68 \pm 0,54^{\mathrm{a}}$ & $57,85 \pm 0,34^{\mathrm{a}, \mathrm{c}}$ \\
\hline Альбумін, г/л & $35,95 \pm 0,78$ & $35,65 \pm 3,43$ & $36,41 \pm 1,9$ & $31,17 \pm 0,67^{\mathrm{a}}$ & $32,86 \pm 1,13^{\mathrm{a}}$ \\
\hline Сечовина, ммоль/л & $6,08 \pm 0,05$ & $7,7 \pm 0,59^{\mathrm{a}}$ & $6,27 \pm 0,13^{\mathrm{b}}$ & $6,97 \pm 0,15$ & $6,2 \pm 0,03^{\mathrm{c}}$ \\
\hline ГГТ, U/I & $16,36 \pm 1,32$ & $21,42 \pm 2,18^{\mathrm{a}}$ & $19,22 \pm 2,61$ & $17,62 \pm 2,49$ & $19,99 \pm 1,47^{\mathrm{a}}$ \\
\hline АлАТ, U/I & $95,6 \pm 7,1$ & $166,35 \pm 7,1^{\mathrm{a}}$ & $58,91 \pm 7,72^{\mathrm{a}, \mathrm{b}}$ & $75,75 \pm 8,11^{\mathrm{a}}$ & $55,4 \pm 5,34^{\mathrm{a}, \mathrm{b}, \mathrm{c}}$ \\
\hline
\end{tabular}

встановлено, що в щурів із нефропатією, яким вводили глутатіон, вміст сечовини наближався до показників контрольної групи тварин (табл. 2), що свідчило про нормалізацію фрільтраційної здатності нирок щодо виведення ними продуктів азотистого обміну.

Концентрацію сечовини в сироватці крові часто використовують як показник контролю функції гломерулярного апарату нирок, і підвищується вона при послабленій видільній фрункції нирок, але більш точною є зміна концентрації креатиніну в плазмі крові. Креатинін фрільтрується через базальну мембрану клубочків нирок і в нормі в тубулярному відділі неорону не реабсорбується. За умов підвищеної концентрації креатиніну в крові його частину активно екскретують клітини тубулярного епітелію. Підвищені рівні креатиніну та сечовини в крові спостерігають за умов ниркової недостатності. Ці показники застосовують для оцінки швидкості клубочкової фрільтрації $[7,8]$.

Такі зміни зумовлені тим, що фролієва кислотає однією з типових сполук, які використовують для моделювання захворювань нирок [9]. Висока її концентрація проявляє загальну токсичну дію на організм, особливо на нирки. Швидка поява кристалів фролієвої кислоти всередині ниркових канальців викликає альтерацію епітелію проксимальних канальців нирки, запальну інфрільтрацію клітин та згодом зумовлює некроз і появу кортикальних рубцювань.
У проксимальному відділі нефрону відбуваються основні процеси реабсорбції профрільтрованих клубочками токсичних речовин, білків, більшої частини води, електролітів тощо. Введення фолієвої кислоти провокує оксидативний стрес. Первинне ушкодження епітелію проксимальних канальців із подальшим розповсюдженням тубулоінтерстиційної дезінтеграції на кіркову, мозкову речовину і сосочки нирки є головною ланкою хронізації нефропатій зі зниженням концентраційної здатності нирок [10].

Значне підвищення активності АлАТ (табл. 1) у сироватці крові на початковому етапі формування нефропатії може свідчити про токсичний вплив високих доз фролієвої кислоти на печінку. На третій день розвитку нефропатії також спостерігали зростання активності ГГТ на 30 \%, а семиденна патологія не характеризувалася значним збільшенням активності досліджуваного фоерменту.

Активність ГГТ у сироватці крові використовують для оцінки стану печінки, й отриманий результат підтвердив токсичне ураження печінки на початковій стадії фрормування нефропатії, спровоковане введенням високої дози фолієвої кислоти. Застосування глутатіону знижувало активність фрерменту, що можна пояснити участю трипептиду в детоксикаційних процесах.

Про загальну інтоксикацію організму під впливом високої концентрації фролієвої кислоти свідчило зниження білоксинтезувальної фрункції 
печінки: концентрація загального білка плазми крові піддослідних тварин достовірно знижувалася протягом усього експериментального періоду, при цьому концентрація альбуміну на початковому етапі дослідження не змінювалася (табл. 1), що може бути пов'язано з дисбалансом синтезу глобулінової фрракції і перерозподілом вмісту багатьох гострофазових білків. За умов застосування глутатіону концентрація загального білка та альбуміну зростала, але не досягала значень, отриманих у контрольній групі тварин.

ВИСНОВКИ. Глутатіон проявляє нефропротекторні властивості, його введення має позитивний вплив на перебіг патології, що підтвер- джується зниженням проявів нефротичного синдрому та поліпшенням фрункціональних показників нирок. Це, очевидно, відбувається за рахунок відновлення структури тканин нирок, а саме клубочкового апарату, епітелію канальців нирок, а також реабсорбційної та фрільтраційної здатності нирок. Найбільш чутливий показник креатинін, вміст якого залежить від концентрації токсиканта, можна використовувати для діагностування стану нирок та підтвердження моделі несропатії.

Перспективи подальших досліджень. Доцільно дослідити механізми антиоксидантного захисту за умов нефропатії, викликаної фролієвою кислотою.

\section{СПИСОК ЛІТЕРАТУРИ}

1. Forman H. J. Glutathione: Overview of its protective roles, measurement, and biosynthesis / H. J. Forman, H. Zhang, A. Rinna // Mol. Aspects Med. 2009. - 30. - P. 1-12.

2. Vivancos P. D. A nuclear glutathione cycle within the cell cycle / P. D. Vivancos, T. Wolff, J. Markovic // Biochem. J. - 2010. - 431. - P. 169-178.

3. Lu S. C. Regulation of glutathione synthesis / S. C. Lu // Mol. Aspects Med. -2009. - No. 30. - P. 42-59.

4. Park E. Y. Increase in the protein-bound form of glutathione in human blood after the oral administration of glutathione / E. Y. Park, N. Shimura, T. Konishi // J. Agric Food Chem. - 2014. - 62 (26). - P. 6183-6189.

5. Burtis C. A. Textbook of Clinical Chemistry and Molecular Diagnosis / C. A. Burtis, E. R. Ashwood, D. E. Bruns. - USA: Elsevier; 2012. - 2238 p.

\section{REFERENCES}

1. Forman, H.J., Zhang, H., \& Rinna, A. (2010). Glutathione: Overview of its protective roles, measurement, and biosynthesis. - Mol. Aspects Med., 30 (1-2), 1-12.

2. Vivancos, PD., Wolff, T., \& Markovic, J. (2010). A nuclear glutathione cycle within the cell cycle. Biochem. J., 431, 169-178.

3. Lu, SC. Regulation of glutathione synthesis. (2009). Mol. Aspects Med., 30, 42-59.

4. Park, E.Y., Shimura, N., \& Konishi, T. (2014). Increase in the protein-bound form of glutathione in human blood after the oral administration of glutathione. J. Agric. Food Chem., 62 (26), 6183-6189.

5. Burtis, C.A., Ashwood, E.R., \& Bruns, D.E. (2012). Textbook of Clinical Chemistry and Molecular Diagnosis. USA: Elsevier

6. Chevalier, R.L. (2006). Obstructive nephropathy: towards biomarker discovery and gene therapy. Nat. Clin. Pract. Nephrol., 2, 157-168.
6. Chevalier R. L. Obstructive nephropathy: towards biomarker discovery and gene therapy / R. L. Chevalier // Nat. Clin. Pract. Nephrol. - 2006. - No. 2. - P. 157-168.

7. Hannemann A. Age- and sex-specific reference limits for creatinine, cystatin $C$ and the estimated glomerular filtration rate / A. Hannemann // Clin. Chem. Lab. Med. - 2011. - No. 50. - P. 919-926.

8. Bocedi A. Biomarkers in kidney disease / A. Bocedi // Springer Science \& Business Media: Dordrecht. 2016. - P. 577-598.

9. Gupta A. Folic acid induces acute renal failure (ARF) by enhancing renal prooxidant state / A. Gupta, V. Puri, R. Sharma, S. Puri // Experimental and Toxicologic Pathology. - 2012. - Vol. 64 (3). - P. 225-232.

10. Гоженко А. И. Патогенез токсических нефропатий / А. И. Гоженко // Актуальные проблемы транспортной медицины. - 2006. - 4 (2). - С. 9-15.

7. Hannemann, A. (2011). Age- and sex-specific reference limits for creatinine, cystatin $C$ and the estimated glomerular filtration rate. Clin. Chem. Lab. Med., 50, 919-926.

8. Bocedi, A. (2016). Biomarkers in kidney disease. Springer Science \& Business Media: Dordrecht, 577598.

9. Gupta, A., Puri, V., Sharma R., Puri S. (2012). Folic acid induces acute renal failure (ARF) by enhancing renal prooxidant state. Experimental and Toxicologic Pathology, 64 (3), 225-232.

10. Gozhenko, A.I. (2006). Patogenez toksicheskikh nefropatiy [Pathogenesis of toxic neuropathies]. Aktualnyye problemy transportnoy meditsiny - Actual Problems of Transport Medicine, 4 (2), 9-15 [in Russian]. 


\section{ВЛИЯНИЕ ГЛУТАТИОНА НА БИОХИМИЧЕСКИЕ ПОКАЗАТЕЛИ СЫВОРОТКИ КРОВИ ПРИ ЭКСПЕРИМЕНТАЛЬНОЙ НЕФРОПАТИИ}

\section{Резюме}

Вступление. Заболевания почек - одна из самых распространенных и актуальных проблем современной медицины. В последние десятилетия активно изучают нефропротекторные свойства различных антиоксидантов с целью предупреждения и коррекции нарушений фрункций почек, однако данные о роли разных антиоксидантов являются фррагментарными и требуют дальнейших исследований.

Цель исследования - изучить влияние глутатиона на изменение биохимических показателей крови в условиях экспериментальной нефропатии.

Методы исследования. Опыты проводили на 90 белых половозрелых крысах-самцах массой 0,160,18 кг. В двух сериях экспериментов нефропатию вызывали путем однократного внутрибрюшного введения фролиевой кислоты в дозах 200 и 250 мг/ке. Глутатион вводили интрагастрально в дозе 100 мг/кг в течение трех и семи дней. Для оценки функционального состояния почек проводили биохимическое исследование крови с определением концентрации креатинина, мочевины, альбумина, общего белка, активности у-глутамилтранспептидазы и аланиламинотранспептидазы.

Результаты и обсуждение. В условиях нефропатии наблюдали увеличение содержания мочевины по сравнению с контрольной группой: на $27 \%$ - на третий день эксперимента, на 15 \% - на седьмой. Введение глутатиона способствовало нормализации исследуемого показателя. Было отмечено повышение, по сравнению с контрольной группой, уровня креатинина в сыворотке крови крыс с нефропатией в 1,5 раза при применении фролиевой кислоты в дозе 200 мг/к2. На седьмой день он увеличился на $17 \%$. В группе животных, у которых нефропатию вызывали фролиевой кислотой в дозе 250 мг/кг, концентрация креатинина повысилась по сравнению с контрольной группой: в 2,4 раза - на третий день эксперимента, на $30 \%$ - на седьмой. Семидневное введение глутатиона приравнивало показатели креатинина подопытных животных к показателям контрольной группы. Об общей интоксикации организма под воздействием высокой концентрации фролиевой кислоты свидетельствовали снижение белоксинтезирующей фуункции печени, возрастание активности у-глутамилтранспептидазы и аланиламинотранспептидазы.

Выводы. Глутатион проявляет нефропротекторные свойства, что подтверждается снижением проявлений нефротического синдрома и улучшением фрункциональных показателей почек. Наиболее чувствительный биохимический показатель в условиях нефропатии - креатинин, содержание которого зависит от концентрации токсиканта, можно использовать для диагностирования состояния почек и подтверждения модели нефропатии.

КЛЮЧЕВЫЕ СЛОВА: нефропатия; креатинин; глутатион; фолиевая кислота.

I. V. Gerush, N. P. Grigorieva, Ye. O. Ferenchuk BUKOVYNA STATE MEDICAL UNIVERSITY, CHERNIVTSI

\section{GLUTATHIONE INFLUENCE ON BIOCHEMICAL INDICES OF BLOOD SERUM IN EXPERIMENTAL NEPHROPATHY}

\section{Summary}

Introduction. Kidney disease is one of the most common problems of modern medicine.

The aim of the study - to determine the effect of glutathione on the change in biochemical findings of blood under conditions of experimental nephropathy.

Research Methods. Experiment was carried out on 90 male albino rats with the body weight of 0.16-0.18 kg. The animals were introduced a single intraperitoneal dose of folic acid (200 or $50 \mathrm{mg} / \mathrm{kg}$ ) for modeling nephropathy. Glutathione was introduced intragastrically $(100 \mathrm{mg} / \mathrm{kg})$ during 3 and 7 days after intoxication with folic acid. The concentration of creatinine, urea, albumin, total protein, activities of $y$-glutamyltranspeptidase activity and alanylaminotranspeptidase were determined.

Results and Discussion. Under conditions of nephropathy the urea content increase by $27 \%$ as compared with the control group on the third and by $15 \%$ on the seventh day of the experiment was observed. The introduc- 
tion of glutathione contributed to the normalization of the content of urea in the blood. An increase in the level of serum creatinine in rats with nephropathy (by using folic acid at a dose of $200 \mathrm{mg} / \mathrm{kg}$ ) in 1.5 times in comparison with the control group was observed. On the seventh day the level of creatinine increased by $17 \%$. In the group of animals where nephropathy was caused by folic acid at a dose of $250 \mathrm{mg} / \mathrm{kg}$, on the third day of the experiment the creatinine concentration increased 2.4 times and by $30 \%$ on the seventh day of the study as compared with the control. Seven-day glutathione influence equates the creatinine values of experimental animals with those of the intact group.

Conclusions. Glutathione shows nephroprotective properties confirmed by a decrease in the manifestations of nephrotic syndrome and improvement of the functional parameters of the kidneys. The content of creatinine depends on the concentration of the toxicant. It can be used to diagnose the kidney condition and confirm the model of nephropathy.

KEY WORDS: nephropathy; creatinine; glutathione; folic acid.

Отримано 26.07.18

Адреса для листування: $€$. О. Ференчук, Буковинський державний медичний університет, пл. Театральна, 2, Чернівці, 58002, україна, e-mail: yelena_f@ukr.net. 